\title{
Morpho-Molecular Characterization of Xanthomonas Axonopodis Pv. Citri Associated with Kinnow (Mandarin) and its Management
}

\author{
Muhammad Iqbal ${ }^{1}$, Muhammad Ehetisham ul Haq ${ }^{1 *}$, Muhammad Kamran ${ }^{1}$, Muhammad Idrees ${ }^{1}$, Shahid \\ Nazir $^{2}$, Ihsan Ullah ${ }^{3}$, Sumera Naz ${ }^{1}$, Shaukat Ali $^{1}$ and Muhammad Zafar Iqbal ${ }^{2}$
}

${ }^{1}$ Plant Pathology Research Institute, Ayub Agricultural Research Institute, Faisalabad, 38000, Punjab, Pakistan; ${ }^{2}$ Agricultural Biotechnology Research Institute, Ayub Agricultural Research Institute, Faisalabad, 38000, Punjab, Pakistan; ${ }^{3}$ School of Agriculture, Policy and Development, University of Reading RG 66AR, UK.

\begin{abstract}
Millions of dollars have been spent annually on quarantines, prevention, eradication and management programs around the globe. The present study was coined to record the incidence of the disease in the Sargodha districts of the Punjab province. Furthermore, isolated bacterium from diseased samples was characterized morphologically and molecularly. The relative efficacy of commercially available antibiotics against the pathogen was evaluated in the lab and in field conditions. A systematic survey of randomly ten localities/sampling sites was conducted for a reliable estimation of citrus canker disease in District Sargodha of Punjab Province. Nine sampling sites showed $90 \%$ the presence of Xanthomonas axonopodis pv. citri and only one site was free of citrus canker disease. Total cellular DNA was isolated from freshly growing aqueous bacterial culture using $\mathrm{CTAB}$ protocol with modifications. Amplification of $581 \mathrm{bp}$ fragment from isolated DNA from bacterial isolates confirmed the presence of pathogen i.e. X. axonopodis pv. citri. The amplified PCR product was purified and further confirmed by sequencing which showed $100 \%$ similarity with 40 nucleotide sequences of $X$. axonopodis pv. citri submitted in NCBI. Relative efficacy of six antibiotics (Streptomycin sulphate, Oxytetracycline, Cefalexin, Kasugamycin, Kanamycin and Levofloxacin USP) against colony growth of $X$. axonopodis pv. citri was evaluated at 50,100 and $150 \mathrm{ppm}$ using disc sensitivity technique. Streptomycin sulphate was found most effective to inhibit the colony growth of the bacterium. Streptomycin sulphate and Oxytetracycline were evaluated against the disease in field conditions. Streptomycin sulphate was found relatively most effective as compared to the Oxytetracycline.

Received | October 22, 2019; Accepted | November 17, 2020; Published | January 31, 2021

*Correspondence | Muhammad Ehetisham ul Haq, Plant Pathology Research Institute, Ayub Agricultural Research Institute, Faisalabad, 38000, Punjab, Pakistan; Email: haq.uaf@gmail.com

Citation | Iqbal, M., M.E. Haq, M. Kamran, M. Idrees, S. Nazir, I. Ullah, S. Naz, S. Ali and M.Z. Iqbal. 2021. Morpho-molecular characterization of Xanthomonas axonopodis Pv. Citri associated with kinnow (Mandarin) and its management. Pakistan Journal of Agricultural Research, 34(1): 8-15.

DOI | http://dx.doi.org/10.17582/journal.pjar/2021/34.1.8.15

Keywords | Kinnow (Citrus reticulata), Xanthomonas axonopodis pv. citri, Streptomycin sulphate, Citrus canker, Disc sensitivity technique
\end{abstract}

\section{Introduction}

$\mathrm{K}$ innow (Citrus reticulata) belongs to the genus "Citrus" and the family "Rutaceae" is an important fruit around the globe (Penjor et al., 2013). It is used as fresh or in processed form like squashes, jams or pickles. Citrus fruit is rich in vitamin $\mathrm{C}$, sugar, citric acid (Economos and Clay, 1999), and have valuable medicinal properties like prevention from hypothermia, malaria and to facilitate blood coagulation (Benavente-García et al., 1997; Manthey et al., 2001; Mohanapriya et al., 2013).

Citrus canker is caused by Xanthomonas axonopodis March 2021 | Volume 34 | Issue 1 | Page 8 
pv. citri, a geographically distributed disease found in more than thirty countries in America, South America, Asia and the Pacific and Indian Ocean island (Gottwald et al., 2002). Catastrophic outbreaks since the last century significantly affected the socio-economics of the citrus growers. Several eradication programs were established to suppress the pathogen i.e. Florida eradication program from 1985 to 1992 where the disease was suppressed by extensive inspection and tree removal (Graham et al., 2004). However, in Manatee County of Florida, the disease reemerged on commercial plantations in June 1997 (Schubert et al., 2001). Annually, more than 50 million dollars, and over 600 personnel were dedicated to the program (Gottwald et al., 2002). In Florida alone, from 1995 to 2005, the running cost for the eradication program plus the compensation to the homeowner for residential citrus destruction and commercial growers has estimated 1 billion dollars (Gottwald, 2007).

Citrus canker is a devastating disease in those regions where warm temperature and rainfall prevails at the time of shoot emergence and fruit development (Shivankar and Ghosh, 2015). On leaves, lesions become visible about 7 to 10 days of the incubation period, firstly on the underside of leaves and then on both sides. With time, the spots become dark brown with raised margins. On leaves, a yellow halo that surrounds the lesion is a typical symptom of the disease. The lesions on the fruit vary in size due to the longer susceptibility of the rind as compared to the leaves. On the stem, the lesions extend to $1.0 \mathrm{~mm}$ depts.

Infected fruit drops prematurely, but if it remains on the tree, it reduces the marketability. On stems, the pathogen survives for a long time in lesions and supports the spread of the disease in successive seasons (Gottwald et al., 2002).

Citrus canker is an extremely costly disease (Jetter et al., 2003). Millions of dollars have been spent annually on quarantines, prevention, eradication, and management programs around the globe. In regions where canker is endemic, management needs integration of cultural practices i.e. windbreaks, sanitation, control of the leafminer with insecticides, and applications of antibiotics (Gottwald and Graham, 2014). The time of the application of the antibiotics and the intervals between the consecutive sprays are of great importance (Ibrahim et al., 2017). The first 90 days after the petal fall are very much crucial; at that time fruit is susceptible to canker. So, it is worthwhile to apply the protective spray of antibiotics during this period on the fruit surface. Hence, to evaluate the efficacy of the different commercially available antibiotics will be very much beneficial for the effective management of the disease.

The present study was aimed to record the incidence of the disease in Sargodha districts of the Punjab province of Pakistan and to characterize the pathogen on a morphological and molecular basis. Furthermore, the study was coined to evaluate the relative efficacy of commercially available antibiotics against the pathogen in the lab and field conditions.

\section{Materials and Methods}

\section{Survey plan for the collection of samples}

A systematic survey was conducted for a reliable estimation of citrus canker disease in District Sargodha of Punjab Province. The district was divided into ten localities/sampling sites and from each sampling site, ten samples were collected at random. Samples were put in polythene bags and data on host locality was recorded. A total of 100 samples were collected from different sites and were transported in the Laboratory of Plant Pathology Section, Ayub Agricultural Research Institute Faisalabad and were stored in the refrigerator at $4^{\circ} \mathrm{C}$ until processing.

\section{Isolation and purification and multiplication of the pathogen}

Diseased leaves were washed with tap water and airdried. Diseased tissues were cut into small pieces and were dipped in $0.1 \% \mathrm{HgCl}_{2}$ solution for two minutes and rinsed twice with distilled water then air-dried. The tissues were macerated in sterile water and filtered by Watman No.1filter paper. Three dilutions i.e. $10^{-1}$, $10^{-2}$ and $10^{-3}$ were made. Modified "Nutrient Glucose Agar" medium was used for bacterial colony isolation. The bacterial isolation dilution plate technique was used. Plates were wrapped and incubated for 48 hours at $25{ }^{\circ} \mathrm{C}$. Bacterial colonies were purified by streaking method and preserved ( $50 \%$ glycerin solution) $4{ }^{\circ} \mathrm{C}$ at for further study.

\section{$D N A$ isolation and PCR}

Total cellular DNA was isolated from freshly growing aqueous bacterial culture using the CTAB 
protocol with modifications (Sambrook et al., 1989). The isolated DNA was quantified and used in PCR for the molecular identification of the pathogen. $X$. axonopodis pv. citri specific primers i.e. Xac01/ $\mathrm{Xac02}$ were selected for the optimization of PCRbased identification protocol (Coletta-Filho et al., 2006; Golmohammadi et al., 2007). The PCR profile consisted of 40 cycles at $94^{\circ} \mathrm{C}$ for 1 minute, $56^{\circ} \mathrm{C}$ for 1 minute, $72^{\circ} \mathrm{C}$ for 1 minute with a final extension step of $72^{\circ} \mathrm{C}$ for 10 minutes. The amplified product was separated on $1.5 \%$ agarose gel after staining with ethidium bromide and visualized under UV gel documentation system (Photonyx Ultra, NYXTecnhnik).

\section{In-vitro evaluation of different antibiotics}

Relative efficacy of six antibiotics (Streptomycin sulphate, Oxytetracycline, Cefalexin, Kasugamycin, Kanamycin and Levofloxacin USP) against colony growth of $X$. axonopodis pv. citri was evaluated at 50, 100 and $150 \mathrm{ppm}$ using disc sensitivity technique (Fairbrother and Martyn, 1951). In the control treatment, sterilized distilled water was used. Petri plates were wrapped with parafilm and incubated at $25^{\circ} \mathrm{C}$. Data were recorded by measuring the inhibition zones area with an ordinary ruler after 72 hours. A Completely Randomized Design (CRD) with three replications was adopted.

\section{Relative efficacy of different antibiotics under field conditions}

After evaluating the antibiotics in the lab, the two antibiotics (Streptomycin Sulphate and Oxytetracycline) exhibited the most efficient to inhibit bacterial colony growth at a most effective dose $(150 \mathrm{ppm})$ were selected for field experiments. The experiment was conducted at a local grower's orchards located in Village No. 296 G.B, Distt. Toba Tek Singh $\left(30.942437^{\circ}, 72.462958^{\circ}\right)$. Five years old Kinnow plants already infected with citrus canker were selected for experiments. All agronomic practices were done. The treatments were applied twice with a successive interval of 10 days. In the control treatment, nothing was applied. The experiment was conducted in Randomized Complete Block Design (RCBD) with three repeats. Data was recorded after 10 days of each application. Disease severity was calculated by randomly taking the bunch of leaves (infected + healthy) from three different locations of a tree. A similar procedure was adopted for the other two replications and leaves (infected + healthy) were mixed. The healthy and infected leaves were counted separately and the severity (\%) was recorded by using the following formula.

$$
\text { AUDPC }=\sum^{n}\left[\left\{\frac{Y_{i}+Y_{(i+1)}}{-}\right\} \mathrm{X}\left(t_{i+1}-t_{i}\right)\right]
$$

Area Under Disease Progress Curve (AUDPC) was calculated using the following formula to analyze the comparative progression of the disease.

$$
\text { AUDPC }=\sum_{i=1}^{n}\left[\left\{\frac{Y_{i}+Y_{(i+1)}}{2}\right\} \mathrm{x}\left(t_{i+1}-t_{i}\right)\right]
$$

Where;

$Y_{i}=$ disease level at $t_{i} ; t_{(i+1)}-t_{i}=$ Time (days) between two disease scores.

\section{Statistical analysis}

The data were analyzed using Analysis of Variance (ANOVA). The efficacy of different treatments was compared by using Fisher's Least Significant Difference (LSD) test (Steel et al., 1997). Data were analyzed using SAS software and data representation was accessed through "Microsoft Office-2013" software (Wilson, 2014).

\section{Results and Discussion}

Prevalence of citrus canker disease in district Sargodha During the survey, 100 samples were collected from 10 localities. Out of which $71 \%$ were infected with citrus canker disease. Nine sampling sites (90\%) showed the presence of $X$. axonopodis pv. citri and only one site were free of citrus canker disease. There was variability in the relative occurrence of citrus canker disease among ten locations (Table 1 ).

The disease incidence ranged from 0 to $100 \%$ with an average of $71 \%$ in the study areas. Maximum incidence $(100 \%)$ of the disease was recorded in Chak No. 3, 33 and Silanwali locations followed by 80, 80,70, 70,60 , and $50 \%$ in Ajnala, Dharema, Chak No. 18, Bhagtawala and Kot Bhai Khan location, respectively. A minimum incidence of $50 \%$ was observed in Chak No. 26 location of District Sargodha.

Iqbal et al. (2016) surveyed the citrus orchards during March, 2015 of Islamabad and Khanpur areas to record the prevalence and severity of the disease from selected orchards. The disease incidence of the 
National Agriculture Research Council, Islamabad and Khanpur orchards ranged from 10\% and 95\% respectively.

Table 1: Prevalence of citrus canker disease in ten localities of District Sargodha of Punjab Province.

$\begin{array}{lll}\text { Sr. No. } & \text { Locality } & \text { Incidence \%* } \\ 1 & \text { Chak No. } 3 & 100 \\ 2 & \text { Chak No. } 18 & 70 \\ 3 & \text { Chak No. } 26 & 50 \\ 4 & \text { Chak No. } 33 & 100 \\ 5 & \text { Ajnala } & 80 \\ 6 & \text { Bhagta Wala } & 70 \\ 7 & \text { Silanwali } & 100 \\ 8 & \text { Mela } & 0 \\ 9 & \text { Kot Bhai Khan } & 60 \\ 10 & \text { Dharema } & 80 \\ & \text { Total } & 71 \\ \text { * Incidence }= & \text { Number of infected samples with citrus canker } \div \text { Total } \\ \text { Samples } \times 100 . & \end{array}$

Al-Saleh et al. (2014) surveyed ten locations of three citrus cultivating areas of the south-western region of Saudi Arabia to study the strains distribution on commercial farms, nurseries and backyard orchards. On leaves, $79.2 \%$ disease incidence and $32.2 \%$ disease severity were recorded. Maximum disease incidence was recorded on Mexican lime in the Jazan region followed by Asser, Balqarn and Sabya, Balqarn and Sabya. The disease severity on Mexican lime in Abu Arish (2.98\%) was higher as compared to Baljursh.

\section{Morphological characteristics of isolated $X$. axonopodis pr. citri}

Less convex margined, translucent, yellow-pigmented, smooth bacterial colonies were observed after 48 hours of incubation on nutrient glucose agar medium. After Gram's staining, red-pink bacterial cells were seen microscopically. $\mathrm{KOH}$ test confirmed that the bacterium is Gram-negative.

\section{Molecular characterization of $X$. axonopodis pv. citri}

Amplification of 581bp fragment from isolated DNA from bacterial isolates confirmed the presence of pathogen i.e. $X$. axonopodis pv. citri. Figure 1 showing

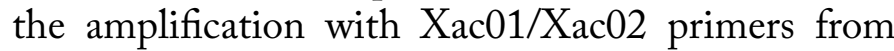
DNA of infected samples while no such fragments were observed in negative control samples having DNA from healthy citrus leaves. The amplified PCR product was purified and further confirmed by sequencing (Gen Bank Accession No. MK 946457) which showed 100\% similarity (Gen Bank Accession No. CP023662) with sequences of $X$. axonopodis pv. citri submitted in NCBI. This optimized PCR based identification protocol could be successfully used to screen the $X$. axonopodis pv. citri infected citrus plants at the molecular level.

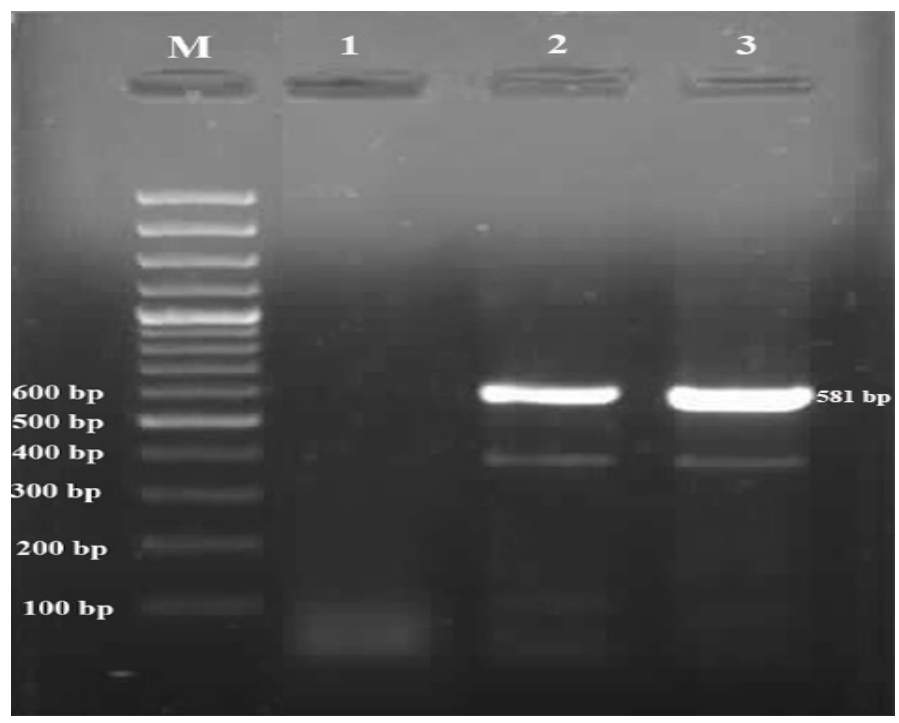

Figure 1: Molecular identification of $X$. citri using $P C R$ technology. Lane M: $100 b p$ ladder, Lane 1 is PCR negative control with $d_{3} \mathrm{H}_{2} \mathrm{O}$ as template, Lane 2 is DNA from cultured bacteria and Lane 3 is positive control having template DNA from known bacteria.

Arshadi et al. (2013) carried rep-PCR fingerprinting on 25 isolates of $X$. axonopodis pv. citri. A relatively high amount of genetic diversity was observed among isolates, indicating that there might be distinct pathotypes of the bacterium present in Malaysia.

Carvalho et al. (2005) investigated $X$. axonopodis pv. citri strains by pulsed-field and plasmid profile analysis. Genetic variation in $X$. axonopodis pv. citri strains were observed isolated from Uruguay, Bolivia and Argentina regions with the similarities varying from 0.62 to 0.83 . The strains from Brazil shown a genetic similarity ranging from 0.83 to 1.00 .

\section{In-vitro evaluation of different antibiotics}

A significant difference in efficacy was seen among the antibiotics at different doses against colony growth of $X$. axonopodis pv. citri. At 300 ppm concentration, Streptomycin Sulphate was found most effective to inhibit bacterial colony growth as compared to other antibiotics. Oxytetracycline was found less effective as compared to the Streptomycin Sulphate but was more with respect to the Cefalexin, Kasugamycin and Flaygyl. Flagyl was found least effective as compared to the other treatments. At $500 \mathrm{ppm}$, a significant 
increase in efficacy of all antibiotics was seen as compared to $300 \mathrm{ppm}$ concentration. Streptomycin Sulphate was found most effective to inhibit bacterial colony growth as compared to other antibiotics. Oxytetracycline was found less effective as compared to the Streptomycin Sulphate but was more with respect to the Cefalexin, Kasugamycin and Flaygyl. Flagyl was found least effective as compared to the other treatments. At 1000 ppm significant increase in efficacy of all antibiotics was seen as compared to $500 \mathrm{ppm}$ concentration. At 1000 ppm Streptomycin Sulphate was found most effective to inhibit bacterial colony growth as compared to other antibiotics. Oxytetracycline was found less effective as compared to the Streptomycin Sulphate but was more with respect to the Cefalexin, Kasugamycin and Flagyl. Flagyl was found least effective as compared to the other treatments. In control where sterilized distilled water was used, no inhibition zone was recorded (Table 2).

Table 2: Efficacy of different antibiotics against $X$. axonopodis pr. citri in lab conditions.

\begin{tabular}{llll} 
Antibiotics & \multicolumn{3}{c}{ Concentrations } \\
& $300 \mathrm{ppm}$ & $\mathbf{5 0 0} \mathrm{ppm}$ & $\mathbf{1 0 0 0} \mathrm{ppm}$ \\
Streptomycin Sulphate & $4.20 \mathrm{E}$ & $5.00 \mathrm{C}$ & $6.27 \mathrm{~A}$ \\
Oxytetracycline & $3.53 \mathrm{G}$ & $4.43 \mathrm{D}$ & $5.23 \mathrm{~B}$ \\
Cefalexin & $3.30 \mathrm{H}$ & $3.53 \mathrm{G}$ & $4.23 \mathrm{E}$ \\
Kasugamycin & $2.83 \mathrm{~J}$ & $3.13 \mathrm{I}$ & $4.00 \mathrm{~F}$ \\
Flaygyl & $2.16 \mathrm{~K}$ & $3.13 \mathrm{I}$ & $3.67 \mathrm{G}$ \\
Control & $0.00 \mathrm{~L}$ & $0.00 \mathrm{~L}$ & $0.00 \mathrm{~L}$
\end{tabular}

LSD (Treatments X Con- 0.16

centrations)

Mean values sharing similar letters do not differ significantly.

Streptomycin sulphate is chiefly synthesized commercially from Streptomyces griseus. The antibiotic has a broad-spectrum use (Schatz et al., 1944), equally effective for Gram-negative and Grampositive bacteria. Both Streptomycin sulphate and oxytetracycline inhibit protein synthesis. X. axonopodis pv. citri is a Gram-negative bacterium, hence, Streptomycin sulphate and oxytetracycline inhibited the colony growth by inhibiting its protein synthesis.

Atiq et al. (2018) evaluated Streptomycin Sulfate and $A$. indica alone and in combinations against $X$. axonopodis pv. citri in lab conditions. Results revealed that Streptomycin alone and in combination with $A$. indica significantly inhibited bacterial growth. Bhure et al. (2019) evaluated four antibiotics streptomycin sulphate, bromopol, Kasugamycin and vitavax at 100 ppm, $250 \mathrm{ppm}$ and $500 \mathrm{ppm}$ concentrations against $X$. axonopodis pv. citri in lab conditions. Among these different antibiotics, streptomycin sulphate@ $@ 500$ ppm was found most effective. Islam et al. (2014) evaluated different antibiotics i.e. chloramphenicol, gentamycin, streptomycin, bacitracin and cefotaxime against $X$. axonopodis pv. citri. Chloramphenicol was found most effective.

\section{In-vivo efficacy of antibiotics against Xanthomonas} axonopodis pv. citri

A significant decrease in disease severity of citrus canker was seen after the applications of the antibiotics, however, in control treatment where nothing was applied, the disease severity increased. After 10 days of the $1^{\text {st }}$ application, Streptomycin Sulphate more efficiently reduced the disease severity as compared to the Oxytetracycline. Oxytetracycline was found effective to lower the disease severity comparing to the control treatment but was less effective as compared to the Streptomycin Sulphate. Data recording after the 10 days interval of the second application of antibiotics revealed a significant decrease in disease severity as compared to the $1^{\text {st }}$ application. Streptomycin Sulphate was found the most effective to decrease the disease severity. In control, where nothing was applied, an increase in disease severity was observed (Figure 2).

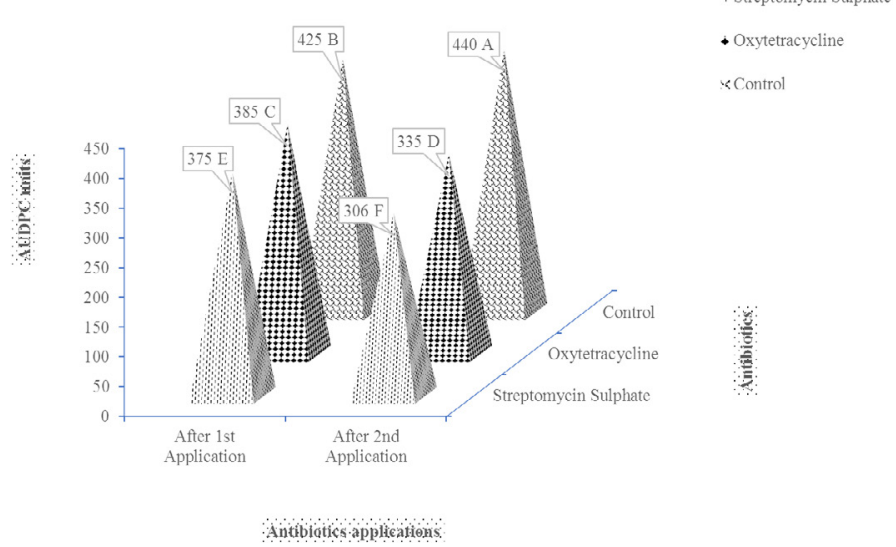

Figure 2: Relative efficacy of antibiotics of different application times against $X$. axonopodis pv. citri under field conditions.

To manage the disease through chemicals applications is a reliable approach, however, environmental hazards are serious concerns that may be minimized by adopting suitable safety measures. Oxytetracycline and Streptomycin Sulphate are systemic, have the basipetal mode of action. Both Streptomycin sulphate 
and oxytetracycline inhibit protein synthesis, bind to $16 \mathrm{~s}$ rRNA of small $30 \mathrm{~S}$ subunit of the bacterial ribosome and interfere with formyl-methionyltRNA attachment to the $30 \mathrm{~S}$ subunit. This results in codon misreading and ultimately protein synthesis is inhibited and the bacterial cell dies (Chopra and Roberts, 2001).

Savitha et al. (2016) sprayed bioagents, botanicals, ISR chemicals, bacteriocides and copper-based fungicides for disease management. The results revealed that the spray of streptomycin sulphate $(500 \mathrm{ppm})+\mathrm{COC}(3 \mathrm{~g}$ L-1) was found most effective to manage the disease.

Rehman et al. (2006) applied different chemicals i.e. Streptomycin sulphate, Trimiltox, Copsykill, Score-250 EC, Streptopan and Procaine penicillin to control citrus canker disease during different seasons. The Streptomycin sulphate @ $1.0 \mathrm{~g} /$ lit found effective against citrus canker on grapefruit.

Shahid et al. (2005) applied Agrimycin-100, Vitavax, Dithane M-45, Benlate and Streptomycin sulphate at $0.2 \%$ concentration on citrus canker infected plants. A significant decrease in disease severity was seen in Streptomycin sulphate, Vitavax, Dithane M-45 and Agrimycin-100 applied plant as compared to control treatment plants where nothing was applied.

\section{Conclusions and Recommendations}

From the present study, the disease survey of Sargodha district and its nearby areas revealed that Chak No. 3, Chak No. 33 and Silanwali areas may be the hotspots for the disease which may be a future threat for a serious outbreak. The molecular characterization of the pathogen may play an important role to adopt appropriates management strategies against the pathogen. Furthermore, from field experiments, we may devise that Streptomycin Sulphate may be used for citrus canker disease management in filed conditions.

\section{Novelty Statement}

The present research revealed the clear scenario of citrus canker incidence in citrus growing regions of the Pakistan. Furthermore, the study is very much important to manage the disease by the use of antibiotics.

\section{Author's Contribution}

Muhammad Iqbal, Muhammad Idrees and Muhammad Zafar Iqbal: Supervised the research experiment.

Muhammad Ehetisham ul Haq and Muhammad Kamran: Field surveys, pathogen isolation and manuscript writeup.

Shaukat Ali and Sumera Naz: Helped in disease data recording and proof reading of the manuscript.

Shahid Nazir: DNA extraction of the Pathogen and Manuscript writeup.

Ihsan Ullah: Genomically characterized the pathogen.

\section{Conflict of interest}

The authors have declared no conflict of interest.

\section{References}

Al-Saleh, M.A., A. Widyawan, A.A. Saleh and Y.E. Ibrahim. 2014. Distribution and pathotype identification of Xanthomonas citri subsp. citri recovered from south-western region of Saudi Arabia. Afric. J. Microbiol. Res., 8: 673-679. https://doi.org/10.5897/AJMR2013.6561

Arshadi, F., K. Sijam and Y.B. Awang. 2013. Genetic diversity of Xanthomonas citri pv. citri, causal agent of citrus canker. J. Plant Prot. Res., 53: 312-316. https://doi.org/10.2478/jppr2013-0047

Atiq, M., M. Aslam Khan, S. Talib Sahi, R. Ahmad, M. Younas, M. Shafiq and Y. Ali. 2018. Appraisal of plant extracts and streptomycin sulfate against citrus canker disease. Arch. Phytopathol. Plant Prot., 51: 824-833. https:// doi.org/10.1080/03235408.2018.1500855

Benavente-García, O., J. Castillo, F.R. Marin, A. Ortuño and J.A. Del Río. 1997. Uses and properties of citrus flavonoids. J. Agric. Food Chem., 45: 4505-4515. https://doi. org/10.1021/jf970373s

Bhure, S., S. Bramhankar, K.Thakur,A.Labhasetwar, S. Isokar, G. Dinkwar, C. Sarode and D. Tathod. 2019. In vitro bio efficacy of different antibiotics, bioagent and botanical against (Xanthomonas axonopodis pv. citri.) causing bacterial canker of acid lime. Int. J. Conserv. Sci., 7: 1789-1782.

Carvalho, F.M.d.S., L.P.C. Caramori, R.P. Leite Júnior. 2005. Genetic diversity of Xanthomonas axonopodis pv. citri based on plasmid profile and 
pulsed field gel electrophoresis. Genet. Mol. Biol., 28: 446-451. https://doi.org/10.1590/ S1415-47572005000300020

Chopra, I. and M. Roberts. 2001. Tetracycline antibiotics: Mode of action, applications, molecular biology, and epidemiology of bacterial resistance. Microbiol. Mol. Biol. Rev., 65: 232-260. https://doi.org/10.1128/ MMBR.65.2.232-260.2001

Coletta-Filho, H., M. Takita, A. De Souza, J. Neto, S. Destefano, J. Hartung and M. Machado. 2006. Primers based on the rpf gene region provide improved detection of Xanthomonas axonopodis pv. citri in naturally and artificially infected citrus plants. J. App. Microbiol., 100: 279-285. https://doi.org/10.1111/j.13652672.2005.02787.x

Economos, C. and W. Clay. 1999. Nutritional and health benefits of citrus fruits. Available at: http://www.fao.org/3/x2650T/x2650t03.htm (Accessed: May 21, 2019).

Fairbrother, R. and G. Martyn. 1951. The disc technique for determining sensitivity to the antibiotics. J. Clin. Pathol., 4: 374. https://doi. org $/ 10.1136 /$ jcp.4.3.374

Golmohammadi, M., J. Cubero, J. Peñalver, J. Quesada, M. López and P. Llop. 2007. Diagnosis of Xanthomonas axonopodis pv. citri, causal agent of citrus canker, in commercial fruits by isolation and PCR-based methods. J. App. Microbiol., 103: 2309-2315. https://doi. org/10.1111/j.1365-2672.2007.03484.x

Gottwald, T.R., 2007. Citrus canker and citrus huanglongbing, two exotic bacterial diseases threatening the citrus industries of the Western Hemisphere. Outlooks Pest Manage., 18: 274. https://doi.org/10.1564/18dec09

Gottwald, T.R. and J.H. Graham. 2014. Citrus diseases with global ramifications including citrus canker and huanglongbing. $\mathrm{CAB}$ Rev. Perspect. Agric. Vet. Sci. Nutr. Natl. Resour., 9: 1-11. https://doi.org/10.1079/ PAVSNNR20149016

Gottwald, T.R., J.H. Graham and T.S. Schubert. 2002. Citrus canker: The pathogen and its impact. Plant Health Progress, 3: 15. https:// doi.org/10.1094/PHP-2002-0812-01-RV

Graham, J.H., T.R. Gottwald, J. Cubero and D.S. Achor. 2004. Xanthomonas axonopodis pv. citri: Factors affecting successful eradication of citrus canker. Mol. Plant Pathol., 5: 1-15. https://doi. org/10.1046/j.1364-3703.2004.00197.x

Ibrahim, Y.E., A.A. Saleh and M.A. Al-Saleh. 2017. Management of asiatic citrus canker under field conditions in Saudi Arabia using bacteriophages and acibenzolar-S-methyl.Plant Dis., 101: 761-765. https://doi.org/10.1094/ PDIS-08-16-1213-RE

Iqbal,S., S.Iftikhar and A. Rasool.2016. Assessment and molecular characterization of citrus canker causing pathotypes. Int. J. Agron. Agric. Res., 8: 93-100.

Islam, M.A., R.M. Mazumdar, S. Islam, M.J. Alam and S.A. Urmee. 2014. Isolation, identification and in vitro antibiotic sensitivity pattern of citrus canker causing organism Xanthomonas axonopodis. Adv. Life Sci., 1: 215-222.

Jetter, K.M., E.L. Civerolo and D.A. Sumner. 2003. Ex-ante economics of exotic disease policy: Citrus canker in California. Exotic pests and diseases, biology and economics for biosecurity. Iowa State Press, Ames, Iowa, pp. 121-149. https://doi.org/10.1002/9780470290125.ch9

Manthey, J.A., N. Guthrie and K. Grohmann. 2001. Biological properties of citrus flavonoids pertaining to cancer and inflammation. Curr. Med. Chem., 8: 135-153. https://doi. org/10.2174/0929867013373723

Mohanapriya, M., L. Ramaswamy and R. Rajendran. 2013. Health and medicinal properties of lemon (Citrus limonum). J. Ayur. Herb. Med., 3: 1095-1100.

Penjor, T., M. Yamamoto, M. Uehara, M. Ide, N. Matsumoto, R. Matsumoto and Y. Nagano. 2013. Phylogenetic relationships of Citrus and its relatives based on matK gene sequences. PLoS One, 8: e62574. https://doi.org/10.1371/ journal.pone.0062574

Rehman, M., N. Chaudhary and M. Nasir. 2006. Citrus canker and its control through chemicals and antibiotics under Sargodha climatic conditions. Pak. J. Phytopathol., 18: 67-69 .

Sambrook, J., E.F. Fritsch and T. Maniatis. 1989. Molecular cloning: A laboratory manual. Cold spring harbor laboratory press.

Savitha, A., A. Kumar, P. Palaiah and G. Ramesh. 2016. Integrated management of citrus canker caused by Xanthomonas axonopodis pv. citri (Hasse) in acid lime (Citrus auruntifolia). Pest Manage. Hort. Ecosyst., 22.

Schatz, A., E. Bugle and S.A. Waksman. 1944. Streptomycin, a substance exhibiting antibiotic 
activity against gram-positive and gramnegative bacteria. Proc. Soc. Exp. Biol. Med., 55(1): 66-69.

Schubert, T.S., S.A. Rizvi, X. Sun, T.R. Gottwald, J.H. Graham and W.N. Dixon. 2001. Meeting the challenge of eradicating citrus canker in Florida again. Plant Dis., 85: 340-356. https:// doi.org/10.1094/PDIS.2001.85.4.340

Shahid, M.M., S. Sahi, M.U. Ghanzafar, M. Inam, I.U. Haq, I. Yasir, M. Sarwar and T. Ahmad. 2005. Evaluation of different toxicants against
Xanthomonas campestris pv. citri (Hasse) Dows. Int. J. Agric. Biol., 7: 121-124.

Shivankar, V.J. and D.K. Ghosh. 2015. Tropical and subtropical citrus health management. Satish serial publishing house.

Steel, R., J. Torrie and T. Dickey. 1997. Principles and practice of statistics: A biomedical approach, New York: McGraw Hill.

Wilson, K., 2014. Microsoft Office 2013. Springer. https://doi.org/10.1007/978-1-4302-6689-1. 